\title{
APLICAÇÃO DO DESENHO AMBIENTAL PARA A BACIA DO CÓRREGO DAS CORUJAS: POTENCIALIDADES E LIMITAÇÕES NA IMPLANTAÇÃO DE UM PARQUE LINEAR
}

\begin{abstract}
Eduardo Mendes de Oliveira ${ }^{1}$, Mariana Corrêa² Soares e Ramon Stock Bonzi ${ }^{3}$
1 Arquiteto na Secretaria Municipal do Verde e Meio Ambiente (SVMA) da cidade de São Paulo, membro da Câmara Técnica de Legislação Urbanística (CTLU) da Prefeitura de São Paulo e especialista em conforto ambiental pela Universidade de São Paulo (USP). E-mail: emoliv@gmail.com

2 Arquiteta paisagista, consultora em planejamento ambiental, graduada pela Faculdade de Arquitetura e Urbanismo da Universidade de São Paulo (FAU USP) e mestranda em Paisagem e Ambiente na pós graduação da FAUUSP. E-mail: marisoarespaisagismo@gmail.com 3 Jardineiro paisagista, professor de jardinagem, especialista em meio ambiente e sociedade pela Fundação Escola de Sociologia e Política de São Paulo (Fespsp) e mestrando na FAUUSP. Email:
\end{abstract} rbonzi@hotmail.com

\begin{abstract}
Resumo
A partir da contextualização sobre a necessidade de novos paradigmas de planejamento urbano capazes de conciliar a ocupação humana com a conservação das bases biofísicas dos territórios são apresentados dois arcabouços teóricos nesse sentido: o Desenho Ambiental e a Infraestrutura Verde. Estuda-se a aplicação dessas ideias em uma área densamente urbanizada: a bacia hidrográfica do Córrego das Corujas, na zona Oeste da cidade de São Paulo. Da análise da situação atual desse curso d'água são apontadas as limitações e as potencialidades paisagísticas e urbanísticas de seu entorno, chegando-se a diretrizes capazes de incrementar a presença do Córrego das Corujas na paisagem urbana. Discorre-se ainda sobre os serviços socioambientais decorrentes de possíveis intervenções ao longo de seu traçado, notadamente, a criação de parques lineares e corredores verdes.
\end{abstract}

Palavras-chave: Desenho Ambiental, Infraestrutura verde, Parques Lineares, Córrego das Corujas, Drenagem urbana.

\section{APPLICATION OF ENVIRONMENTAL DESIGN FOR THE CORUJAS WApplication}




\title{
APPLICATION OF ENVIRONMENTAL DESIGN FOR CORUJAS CREEK BASIN: POTENTIAL AND LIMITATIONS FOR A LINEAR PARK IMPLEMENTATION
}

\begin{abstract}
From the context of the need for new paradigms of urban planning capable of reconciling human occupation and the conservation of the biophysical bases of the territories are presented two theoretical frameworks in this regard: the Environmental Design and Green Infrastructure. This study presents the application of these ideas in a densely urbanized area: the basin of the Corujas Creek, on the western zone of Sao Paulo city. The analysis of the current situation of this stream are pointed out the limitations and potential of urbanism and landscape of its surroundings, coming to guidelines can increase the presence of the Corujas Creek in the urban landscape. It also talks about the social and environmental services related to possible interventions along its route, notably the creation of linear parks and greenways.
\end{abstract}

Key words: Environmental Design, Green Infrastructure, Linear Parks, the Corujas Creek, urban drainage.

\section{INTRODUÇÃO}

A questão ambiental tem conseguido ganhar espaço na cidade de São Paulo, graças à pressão da população e da sociedade civil organizada, resultando em um nítido movimento de valorização do verde.

No entanto, ainda parece prevalecer a ideia da cidade dissociada da natureza, um equívoco como nos ensinam autores como Spirn (1995), Hough (1998) e McHarg (2000). Fruto do processo histórico de "ruptura progressiva entre o homem e o entorno" (Santos, 1994, p. 05), a dicotomia homem/natureza revela-se com muita clareza na relação que nós, habitantes de São Paulo, estabelecemos com os nossos rios. Como afirma Bartalini, "o poder público tem uma tradição de desprezo aos rios, canalizando-os e ocupando as áreas de várzea" (2009). Já a população comumente associa os corpos d'água a aspectos negativos como esgoto e inundações (2006).

Estas concepções de mundo penetraram também a esfera tecnocientífica, como pode 
ser observado no pouco valor que as práticas projetuais e de planeamento urbano costumam conferir aos suportes físicos dos territórios.

As consequências são evidentes: a pequena importância conferida à topografia, hidrografia, geologia e vegetação durante a ocupação do território está fortemente ligada a problemas atuais como inundações, deslizamentos, ilhas de calor, baixa umidade do ar, altos níveis de ozônio e poluição atmosférica, entre outros.

Ademais, neste cenário de "emergência socioambiental" (Veiga, 2007, p. 10), o setor de construção civil tem sido cada vez mais recriminado por sua baixa eficiência energética, consumo exacerbado de recursos naturais e alta emissão de $\mathrm{CO}_{2}$. Entendemos que é questão de tempo para que os ambientes construídos, e não mais os combustíveis fósseis, sejam considerados os grandes vilões do meio ambiente'.

É neste complexo contexto que o Desenho Ambiental e a Infraestrutura Verde sinalizam com ideias e conceitos que, ao reconhecer as potencialidades e as limitações colocadas pelas bases físicas dos territórios, são capazes de conectar pessoas, espaços livres e a(s) natureza(s) nas cidades, ajudando assim na construção de uma sociedade mais "sustentável".

\section{DESENHO AMBIENTAL}

Franco (1997) explica que a expressão Desenho Ambiental remete a "Environmental Design" e "exprime uma intenção de projeto que transcende as questões estéticas, culturais e funcionais de que trata o paisagismo" (p. 10).

O início dessa escola pode ser rastreado até o pós-segunda guerra, quando a dimensão da crise ambiental desencadeou uma "nova linha de trabalho para os arquitetos paisagistas, baseado na visão ecológica do mundo". (ibid, p.31).

1 Basta lembrar a narração de abertura da série de documentários E2 Series, da PBS, exibida no Brasil pela Management TV: "They use $40 \%$ of the world's energy, emit $50 \%$ of its greenhouse gases. "They" are not the cars we drive. "They" are the buildings where we work, live, and grow. Buildings designed with an unconscious disregard for nature. Adopting sustainable alternatives is not only a matter of progress, it's a matter of survival". 
Seus fundadores são os arquitetos lan L. McHarg e L. Halprin. Ao comentar sobre a importância do seminal Design with Nature, de McHarg, Magalhães afirma que o livro, com seu método de sobreposição de mapas temáticos (layer cake), ainda é uma referência para o ordenamento do território:

McHarg começa por fazer o inventário ecológico da área de estudo, através de factores que considera indicadores representativos dos processos naturais. Em função destes factores, determina a capacidade intrínseca do território para a implantação das actividades humanas. (...) Esta capacidade era representada em cartas específicas para cada uso (...) A integração das diversas cartas de aptidão era realizada a partir de uma matriz de incompatibilidades dos vários usos do solo considerados, dando origem a uma carta síntese que informava sobre a aptidão do solo aos vários tipos de atividade, (...) incluindo os usos múltiplos possíveis. (2001, p. 261)

Como podemos observar, McHarg incorporou ao planejamento urbano uma nova dimensão: a ecológica. Com isso, o Desenho Ambiental inseriu a ideia de processo nas práticas de projeto e de planejamento, conforme explica Franco:

O Desenho Ambiental pressupõe o conceito ecossistêmico em que a ação antrópica esteja incluída, bem como a idéia de nega-entropia inserida na ciclagem dos recursos, na preservação e na conservação ambientais. Isso no plano sócio-cultural se traduz pela otimização dos recursos energéticos e participação comunitária, tanto no processo da criação das propostas para o ambiente quanto no monitoramento na gestão destas na fase posterior, ou pós-projeto (uso e avaliação pós-ocupação). (1997, p.11)

Vale destacar que nessa verdadeira revolução do planejamento urbano e regional (Franco, 1997, p. 32), McHarg conferiu lugar de destaque para o papel das bacias hidrográficas. 


\section{INFRAESTRUTURA VERDE}

Emergindo da base teórica da Ecologia da Paisagem, o termo Infraestrutura Verde surge em meados dos anos 90 (Firehock, 2010, p.01) como "uma maneira de reconhecer e aproveitar os serviços que a natureza pode realizar no ambiente urbano" (Cormier \& Pellegrino, 2008).

Segundo Ferreira e Machado (2010) a infra-estrutura verde é definida por uma rede de áreas naturais e áreas abertas (open spaces) fundamentais para o funcionamento ecológico do território, contribuindo para a preservação dos ecossistemas naturais, da vida selvagem, para a qualidade do ar e da água e para a qualidade de vida dos cidadãos. (p. 69)

Além de evidenciar que o paisagismo pode ser mais que o mero embelezamento das cidades, a Infraestrutura Verde é dotada de grande potencial educacional uma vez que suas tipologias emulam ou evidenciam os processos da natureza. Ao aceitarmos a afirmação de Hough (1998) de que "fazer visíveis os processos é um componente essencial da consciência ambiental e uma base necessária para a ação" (p. 30), a Infraestrutura Verde desponta, ainda, como potencialmente motivadora de profundas mudanças sociais.

Segundo Cormier e Pellegrino (2008, p. 139) "os projetos de infra-estrutura verde podem ser os trabalhos mais duradouros de nosso tempo, se pudermos conectá-los às pessoas".

Franco problematiza o conceito ao apontar que Infraestrutura Verde "significa diferentes coisas dependendo do contexto no qual ele é empregado" (2010, p. 141). Para a autora, no Planejamento e Desenho Ambiental a Infraestrutura Verde pode ser entendida como uma rede interconectada de áreas verdes naturais e outros espaços abertos que conservam valores e funções ecológicas, sustentam ar e água limpos e ampla variedade de benefícios para as pessoas e a vida selvagem que deverão nortear as ações de planejamento e desenvolvimento territoriais que deve garantir a existência dos processos vivos no presente e no futuro. (ibid) 
Benedict e McMahon chamam a atenção de que a infraestrutura verde também abarca elementos naturais que não se restringem à vegetação: "Os sistemas naturais protegidos por uma rede de infraestrutura verde não são todos verdes. Rios e córregos são elementos críticos de quase todos os sistemas de Infraestrutura Verde" (2006, p. 14 , tradução nossa) $)^{2}$.

\section{A ÁREA DE ESTUDO}

Nascendo próximo ao chamado espigão da Avenida Paulista, na zona oeste da cidade de São Paulo, o Córrego das Corujas separa os bairros de Vila Madalena e Vila Beatriz, e, à jusante estabelece a fronteira entre Pinheiros e Alto de Pinheiros. Após percorrer cerca de 2.800 metros, o Corujas deságua no Rio Pinheiros.

A região circunscrita por sua bacia hidrográfica é caracterizada por baixa verticalização, vias arborizadas, calçamento irregular, topografia por vezes acidentada, sobretudo nas imediações da Avenida Heitor Penteado. De perfil residencial, o "Vale das Corujas" é habitado, majoritariamente, pela classe média alta.

2 "Moreover, the natural systems protected by a green infrastructure network are not all green. Rivers and streams are critical elements of almost any green infrastructure system." 

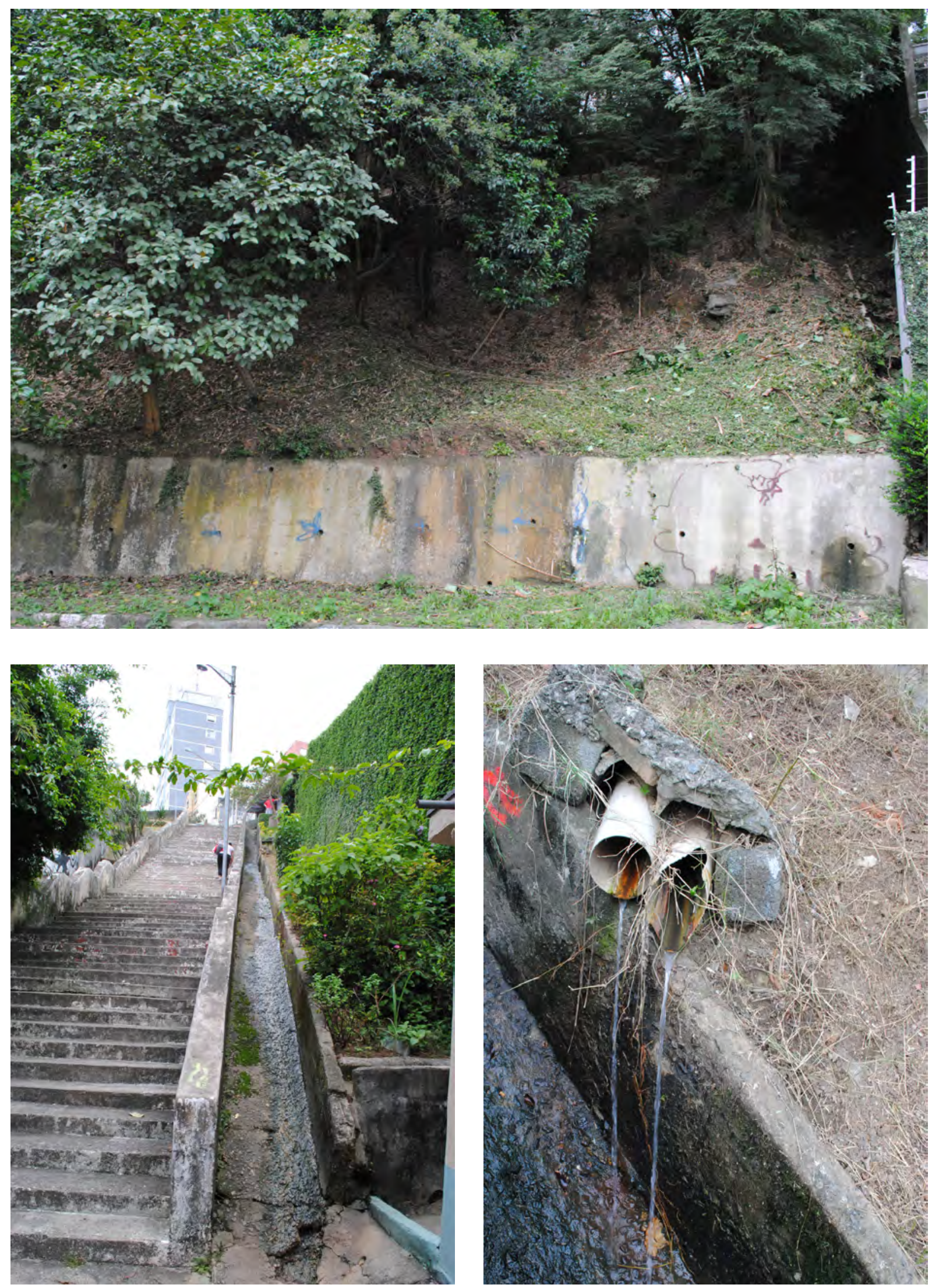

Figuras 1, 2 e 3: Umidade constante em muro de contenção e bica improvisada em escadaria da Rua Orós sinalizam região da nascente. 


\section{Revista LABVERDE}

O Córrego das Corujas foi retificado na década de 40, pouco depois da Companhia City começar o arruamento para o loteamento do Alto de Pinheiros, em 19373. Hoje se encontra totalmente tamponado, exceto em um pequeno trecho em que o ribeirão "banha" a Praça Dolores Ibarruri e o recém-inaugurado Parque das Corujas, parque linear contíguo, de $2.000 \mathrm{~m}^{2}$, entregue pela subprefeitura de Pinheiros em dezembro de 2011.
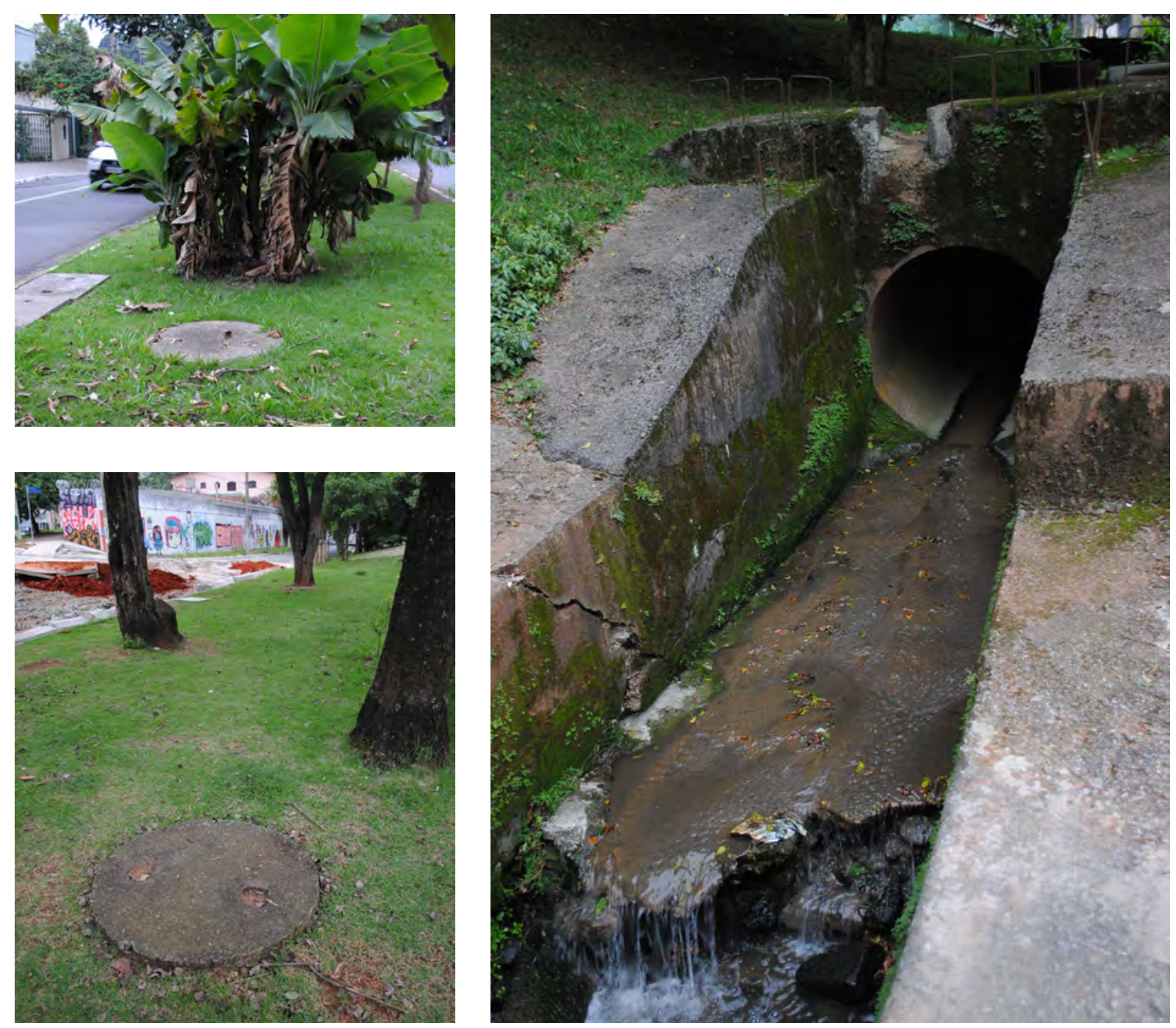

Figuras 4, 5 e 6: córrego inicia sua jornada canalizado sob o canteiro central na Avenida das Corujas, para se revelar na Praça Dolores Ibarruri.

3 Informação disponível em: < http://www.prefeitura.sp.gov.br/cidade/secretarias/ subprefeituras/pinheiros/historico/index.php?p=472>. Acesso em 26 de abril de 2012. 
A Praça Dolores Ibarruri, uma área de $24.000 \mathrm{~m}^{2}$ mais conhecida como Praça das Corujas, tem sido frequentemente considerada referência para projetos paisagísticos, seja por conta da presença de elementos da chamada Infraestrutura Verde para a drenagem urbana, seja pela participação da comunidade, conforme relata Martins:

Em 2006, de modo a revitalizar a área, tornando-a mais movimentada e segura, um conjunto de moradores do entorno imediato da praça se reuniram em busca de propostas para um novo projeto que transformasse a área em um espaço recreativo agradável para a população do bairro, ao mesmo tempo em que resolvesse questões com relação à poluição do córrego canalizado e aos problemas de inundações e drenagem pluvial do perímetro de intervenção.

(2012, p. 29).

Embora apresente alguns problemas, como veremos mais adiante, a Praça das Corujas é sem dúvida um marco na transição do manejo das águas pluviais em São Paulo, um sinal de que o higienismo do século XX pode estar com seus dias contados. Conforme apurou Martins, após a revitalização da praça em 2009 e 2010, ocasião em que ganhou elementos de infraestrutura verde, houve diminuição nos episódios de alagamento junto à Rua Pascoal Vita (p.59). Além disso, segundo moradores da área e visitantes frequentes da praça, o projeto paisagístico parece ter se tornado um local agradável e atrativo, de uso intenso para passeio de adultos, crianças e seus animais de estimação. (...) Todos concordam que a praça tornou-se referencial no bairro, facilitou o convívio e o passeio na área e valorizou de modo substancial as casas da região. (ibid) .

Nas visitas de campo foi possível confirmar as impressões de Martins de que os usuários da Praça estão muito satisfeitos com ela. 


\section{Revista LABVERDE}
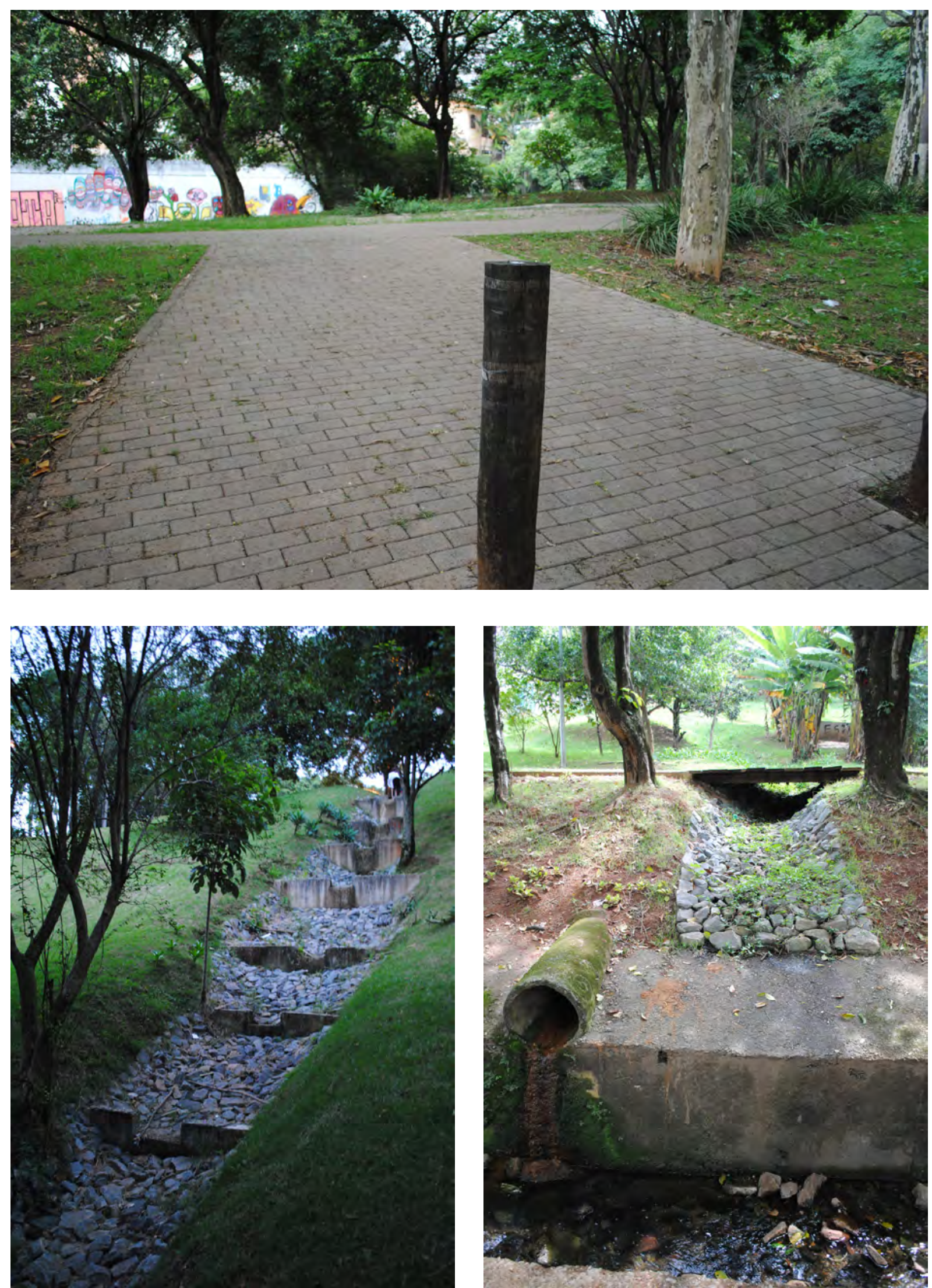

Figuras 7, 8 e 9: piso drenante e biovaletas - elementos de infraestrutura verde presentes na Praça Dolores Ibarruri. 
$\mathrm{Na}$ área de estudo também é possível identificar outro elemento que desempenha um papel fundamental na superação do modelo higienista ${ }^{4}$ de drenagem urbana, embora, paradoxalmente, ainda opere em sua lógica: o Programa Córrego Limpo, ação conjunta do Governo de São Paulo, Prefeitura e Sabesp com vistas a sanear 300 córregos no município de São Paulo.

Sobre a qualidade da água que o programa pretende alcançar, Travassos explica que a meta referencial para os rios é relativa à classe 3 da resolução 357 do Conama, uma água que possa ser convertida em potável a partir de um tratamento simples. (...) Esse padrão possibilita também a recreação, a irrigação e a pesca, uma vez que exige a ausência de substâncias tóxicas na água. (2010, p. 137).

Evidentemente, águas nessas condições possibilitam que projetos de parques lineares não se limitem a mostrar seus rios e córregos - o que já não deixa de ser um feito notável - mas também possibilita que as águas se tornem elementos passíveis de uso, contribuindo para a efetiva (e afetiva) apropriação desses espaços pela população.

Em dezembro de 2011 o Programa deu como concluída a sua intervenção no Córrego das Corujas, em seu montante trecho a céu aberto (Avenida Corujas até Rua Romeu Perroti) $)^{5}$. No entanto, em visita a campo, foi registrado (fig.11) o que parecia ser despejo de esgoto no trecho em que o ribeirão corre a céu aberto, junto no Parque das Corujas.

$4 \quad$ Franco (1997, p. 78) explica que "o movimento higienista desde suas origens (fins do séc. XVIII), valeu-se da 'teoria dos meios'. Esta insistia em que os males eram advindos da estagnação de todo o tipo - água, lixo e homens. Dessa forma a circulação transformou-se na palavra de ordem da engenharia sanitária". Isso permite entender porque, aparentemente, todo o sistema de drenagem de São Paulo parece ter sido pensado de modo a fazer a água 'sumir' o mais rapidamente possível de nossa vista.

5 Segundo o site <http://www.corregolimpo.com.br/corregolimpo/areas_despoluidas/areas_ despoluidas.asp>. Acessado em 26 de abril de 2012. 


\section{Revista LABVERDE}

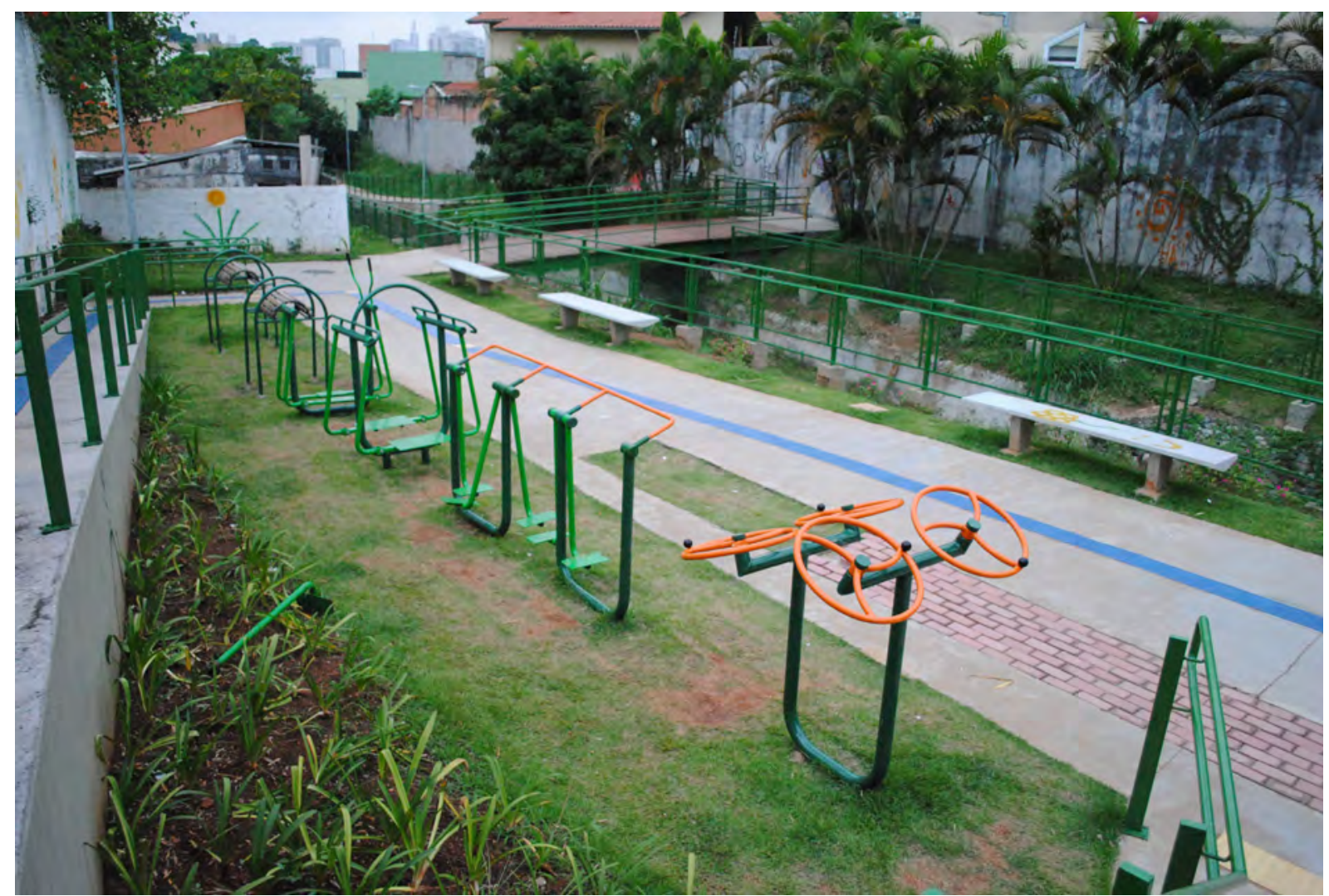

Figura 10: o recém-inaugurado Parque das Corujas.

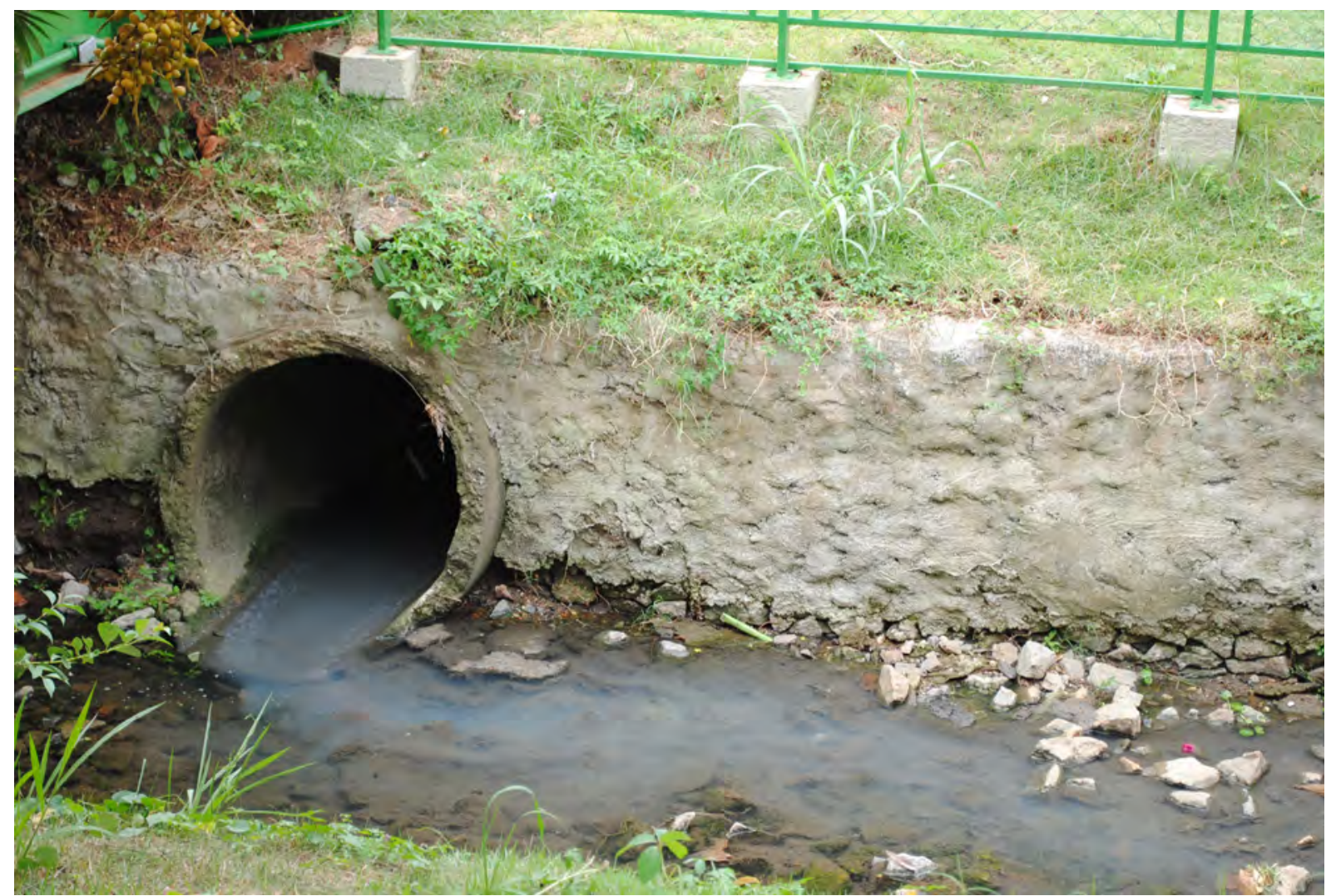

Figura 11: córrego limpo? 


\section{PARQUES LINEARES - CORREDORES VERDES}

A criação de espaços verdes públicos, consubstanciados naquilo que a literatura chama de caminhos verdes ${ }^{6}$, originalmente "greenways", atende adequadamente à dupla função de criar áreas que atendam a demandas urbanas, mas que possam conviver com cheias periódicas.

Do ponto de vista histórico, os projetos de Olmsted são considerados precursores da prática dos caminhos verdes, assim como os de Howard, com sua teoria de cidades jardim.

Apesar da manutenção do termo historicamente construído e sobre o qual se encontra uma vasta bibliografia conceitual e empírica, recentemente o conceito universal de caminhos verdes evoluiu desta ideia para a de corredores verdes e, mais recentemente ainda, passa a integrar uma nova categoria, a infraestrutura verde ${ }^{7}$. No Brasil, segundo Travassos (2010), dá-se o nome de parques lineares às áreas verdes lindeiras aos rios ou a outras estruturas lineares nos espaços urbanos, ou corredores ecológicos, quando no âmbito regional e fora de malhas urbanas.

No município de São Paulo, a partir de uma "pesquisa e análise de aplicação de instrumentos em planejamento urbano ambiental" ${ }^{8}$, que define e conceitua as tipologias do Sistema de Espaços Livres e Áreas Verdes - SELAV, os órgãos responsáveis da

6 Os "greenways", na literatura chamados de caminhos verdes, segundo Ahern (1995), podem ser conceituados como redes de terrenos que contem elementos planejados, desenhados e geridos para múltiplos objetivos, inclusos ai o ecológico, o recreacional, o cultural, o estético, entre outros. 7 "Conceito emergente de planejamento e desenho principalmente estruturado por uma rede híbrida hidrológica e de drenagem, completando e ligando áreas verdes existentes com infraestrutura construída, fornecendo funções ecológicas”. (AHERN, 2008, apud INVERDE, 2010.)

8 O Departamento de Parques e Áreas Verdes - DEPAVE, da Secretaria Municipal do Verde e Meio Ambiente (SVMA) solicitou ao Laboratório de Habitação e Assentamentos Humanos da Faculdade de Arquitetura e Urbanismo da Universidade de São Paulo (LabHab) uma pesquisa que define o Sistema de Espaços Livres e Áreas Verdes _ SELAV_ como o conjunto dos espaços públicos ou particulares vegetados, considerados de interesse público para o satisfatório cumprimento de finalidades paisagísticas, ecológico-ambientais, funcionais, produtivas, de lazer e práticas de sociabilidade. A pesquisa define, as possíveis tipologias e parâmetros para as áreas verdes urbanas. Estabelece ainda as finalidades de cada uma delas para o município de São Paulo. 
prefeitura, admitem como definição de caminho verde, "área verde linear associada ao tráfego de pedestres" (p.21) Assim, por definição, no município, o termo caminhos verdes passa a designar as calçadas devidamente arborizadas, com larguras definidas pelo Programa Calçadas Verdes, desde que sejam permeáveis em, pelo menos, $60 \%$ das suas áreas.

Ainda de acordo com o SELAV, o termo parque linear, designa "o parque linear da rede hídrica, que é área verde associada à rede hídrica" (p.16). Os objetivos dos parques lineares são: proteger ou recuperar os ecossistemas lindeiros aos cursos e corpos d'água, conectar áreas verdes e espaços livres de um modo geral, controlar enchentes e prover áreas verdes para o lazer.

O presente artigo adota, a partir deste ponto, para caminhos verdes e parques lineares as definições do SELAV e para se referir de forma genérica às áreas verdes urbanas que tenham como característica espacial principal a linearidade e que formem redes criando vínculos e conexões em escalas diversas, utilizará a terminação corredores verdes.

Admite que redes de corredores verdes são espaços livres lineares que ligam grandes áreas não lineares ou grandes manchas de espaços naturais, constituindo sistemas de espaços, planejados, projetados e geridos para diversas finalidades, incluindo objetivos ecológicos, recreativos, culturais, estéticos e produtivos, compatíveis com o conceito de sustentabilidade. (Ferreira, Machado, 2010)

Uma contribuição relevante à classificação dos "greenways", aqui denominados corredores verdes, é proposta por Ahern (1995). O autor discorre acerca de algumas ideias-chave importantes para a compreensão do conceito e suas possíveis classificações da mesma forma que embasam as perspectivas discutidas no presente artigo: que os corredores verdes têm como característica espacial principal a linearidade; que a rede criada por esses caminhos deve criar vínculos e conexões espaciais em várias escalas; que são predominantemente multifuncionais; que a estratégia de planejamento deve levar em conta as questões ambientais e econômicas (o autor não cita as questões sociais a não ser que estejam compreendidas nas ambientais, mas vale ressaltar que são relevantes para o presente artigo); e que os corredores verdes devem ser considerados como um complemento do planejamento físico e de paisagem, e não como seu substituto. (Ahern apud Travassos, 2010) 
$\mathrm{Na}$ busca por uma adequação aos novos paradigmas propostos pelo planejamento ambiental urbano, o parque linear ${ }^{9}$ constitui a principal estratégia de intervenção do Programa de Recuperação Ambiental de Cursos d'Água e Fundos de Vale e o principal elemento da Rede Hídrica Estrutural, estabelecidos no Plano Diretor Estratégico do Município de São Paulo - PDE. (São Paulo, 2002.)

A partir da introdução, contextualização e das definições acima esclarecidas, a questão que se coloca é a cerca do desafio que representa a aplicação prática dos conceitos abordados em um córrego localizado em meio a uma ocupação urbana densa, regular e bem consolidada e que detém a maior parte do seu curso canalizado e tamponado. Há trechos do córrego onde não se tem nem mesmo vestígios de sua passagem, posto que a ocupação deu-se de modo indiferente às limitações e potencialidades do sítio natural original da micro bacia em estudo.

\section{MOBILIDADE URBANA}

Sob uma ótica histórica, Searns (1995) estabelece três gerações de "greenways"10, a primeira geração tem início antes do século 16 e vai até a década de 1960 e está intimamente vinculada à questão do patrimônio. Na segunda geração, entre a década de 1960 e 1985, a ênfase dos projetos de "greenways" era trazer a natureza para a cidade, mas também uma resposta à demanda de rotas não motorizadas, como alternativa à dominação do transporte individual, o automóvel. A terceira geração que permanece até hoje passou a compreender usos múltiplos em seus objetivos e tornou a questão ambiental praticamente obrigatória no equacionamento dos projetos urbanos. (Travassos, 2010)

A classificação de Searns evidencia em que período a demanda pela circulação não motorizada tornou-se imperativa. Hoje, esta possibilidade está diretamente associada à qualidade de vida que uma cidade pode garantir aos seus habitantes.

\footnotetext{
9 Entenda-se pelo termo parque linear aqui utilizado, a definição do SELAV acima descrita.

10 "Greenways" aqui se refere ao termo geral historicamente construído, neste artigo traduzido por corredor verde.
} 
Em São Paulo as peculiaridades do desenho urbano, propiciam a existência de consideráveis extensões de terra, de sobras do traçado viário, de propriedade pública ou particular, sem destinação. Segundo Pereira Leite (2011), a proposição de uma alternativa viável de deslocamento que não negue, mas reduza o impacto ambiental do sistema viário no desenho e planejamento urbano é condição para desonerar áreas atualmente comprometidas com a circulação de veículos e impedidas de desempenhar funções ambientais e sociais. Calçadas largas (com caminhos verdes) viabilizando um sistema contínuo de circulação de pedestres e, onde haja a possibilidade, de ciclovias que respondam aos excessos do sistema viário e da engenharia de tráfego integram uma proposta de modernização que não se propõe apenas a adotar novas e efêmeras formas e conceitos de espaço público, mas que limita o uso do automóvel como principal força motriz do desenho da cidade. (Pereira Leite, 2011. p. 169)

\section{PROJETOS INSTALADOS NA ÁREA}

A Praça Dolores Ibarruri foi revitalizada nos anos de 2009 e 2010. Com projeto dos arquitetos Paulo Pellegrino e Elza Niero e estudo hidrológico realizado por professores do departamento de hidráulica da POLI-USP, a praça foi pensada para receber uma série de intervenções da chamada infraestrutura verde a fim proporcionar a retenção e infiltração local de águas pluviais e o retardamento do escoamento superficial. Tratase de uma estratégia para evitar sobrecargas nas galerias de águas pluviais, cada vez mais pressionadas pelo processo de impermeabilização da cidade, mas que não se limita a isso: além de ajudar no controle às enchentes, as tipologias de infraestrutura verde também desempenham outras funções tais como conforto ambiental, suporte à biodiversidade e notadamente a redução da poluição difusa das águas por meio da vegetação.

Conforme levantado por Martins (2012), o projeto original sofreu uma série de modificações. Essas comprometem parcialmente a eficiência da infraestrutura verde implantada o que tem por consequência final o prejuízo do usuário da praça.

O projeto original previa as seguintes intervenções ligadas às funções de drenagem: por meio de biovaletas para lagoas pluviais, conectadas ao Córrego das Corujas por meio de vertedouros e gabião para os episódios de extravasamento. 
pavimento permeável assentados em colchões drenantes.

$\diamond \quad$ plantio de forrações e arbustos nos taludes do córrego, a fim de promover contenção e 'renaturalização'.

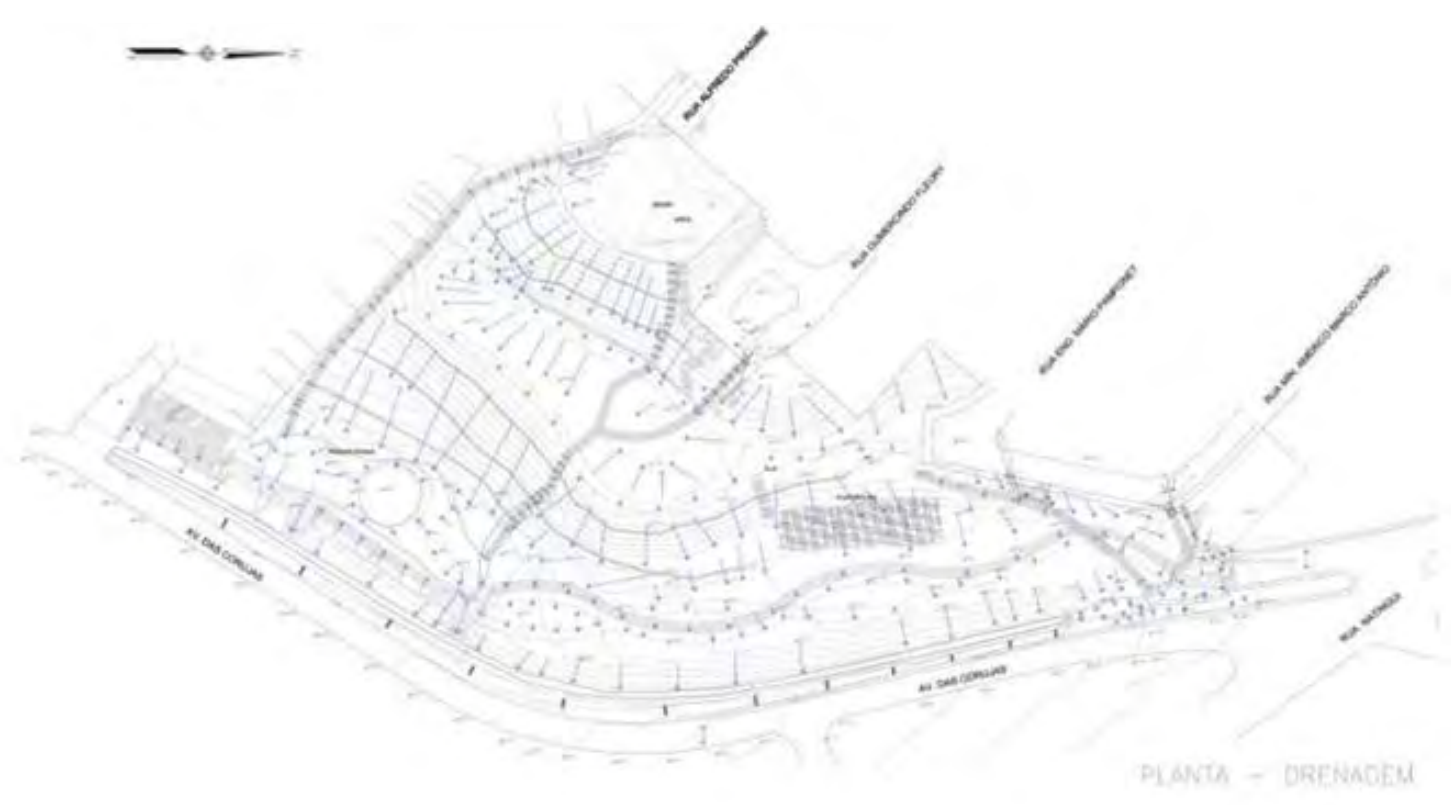

Figura 12: projeto executivo de drenagem. Fonte: arquitetos do projeto.

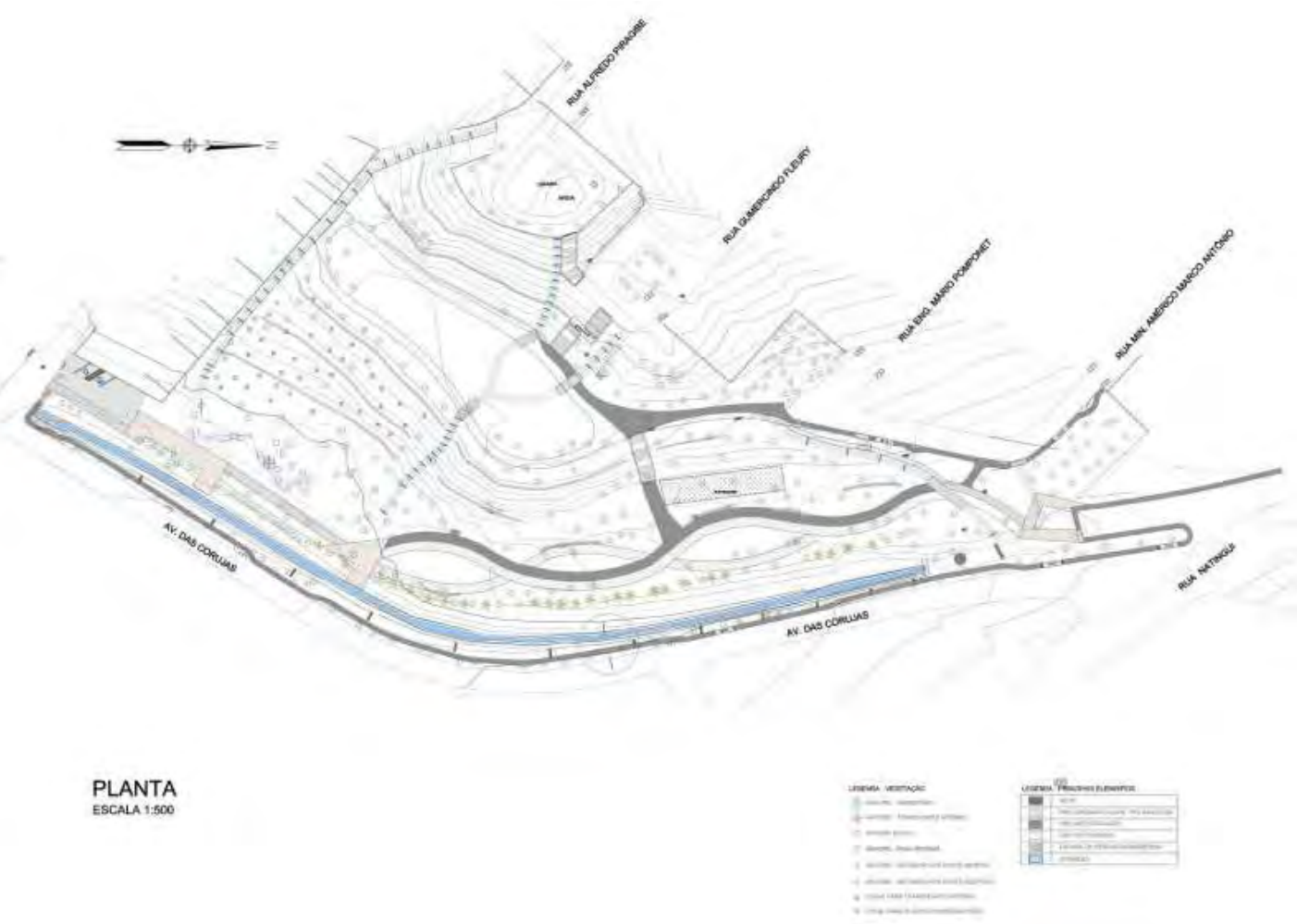

Figura 13: projeto paisagístico executivo. Fonte: Arquitetos do projeto. 
Martins relata que "empecilhos não possibilitaram que a construção integral do projeto executivo fosse conduzida como especificado pelos arquitetos e engenheiros contratados" (p. 43).

Em relação às obras relacionadas a funções de drenagem, Martins identificou as seguintes mudanças:

$\diamond \quad$ parte das biovaletas foram concretadas.

$\diamond \quad$ as lagoas pluviais não foram executadas.

$\diamond \quad$ modificações nos pisos drenantes.

$\diamond \quad$ instalação de valetas convencionais não previstas no projeto.

$\diamond \quad$ espécies vegetais previstas em projeto não foram plantadas ou foram substituídas por outras.

$\diamond \quad$ não foram feitas as alterações em calçadas a fim de direcionar a água da rua para as biovaletas.

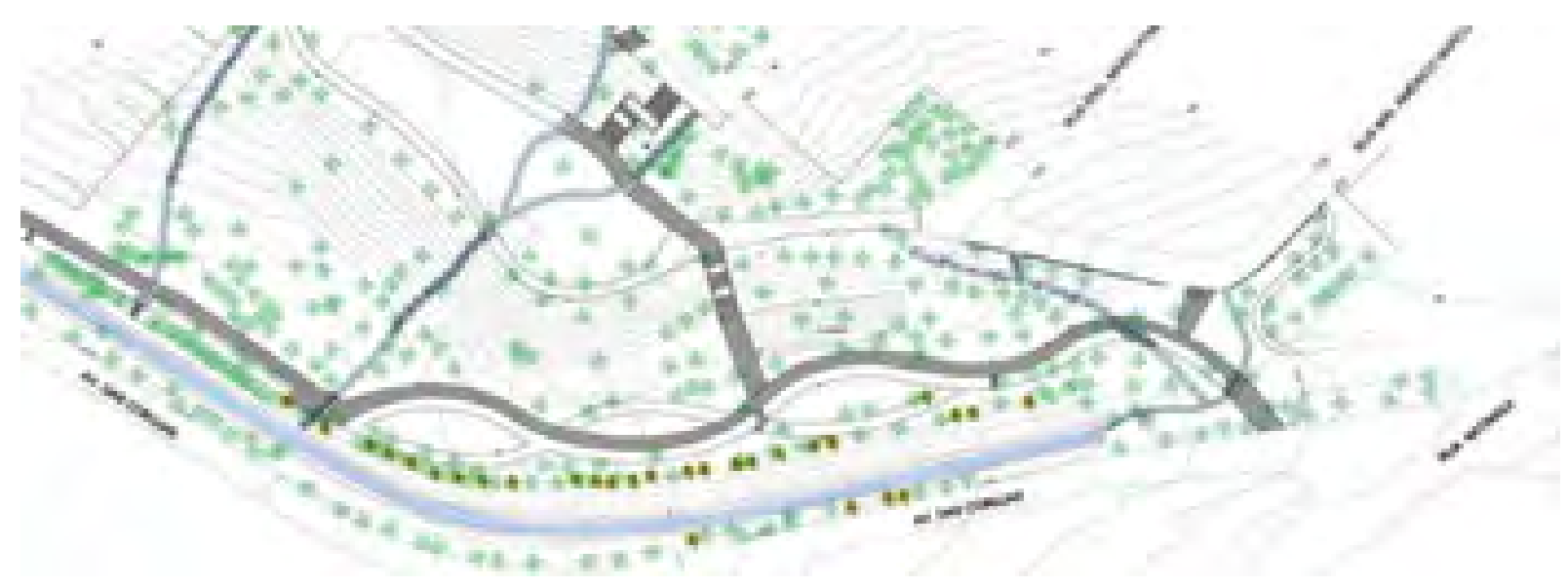

Figura 14: projeto paisagístico as-built. Fonte: Martins (2012). 
Durante visita a campo foi possível observar alguns problemas que parecem diretamente ligados à não observação do projeto original:

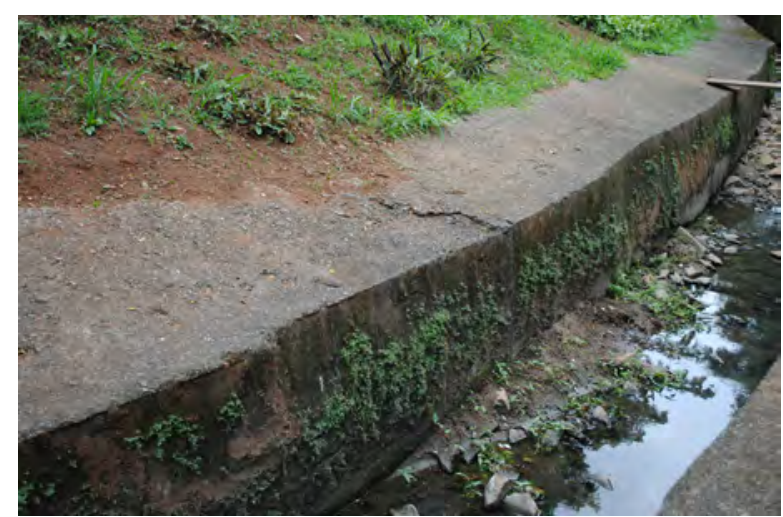

Figura 15: assoreamento do córrego.

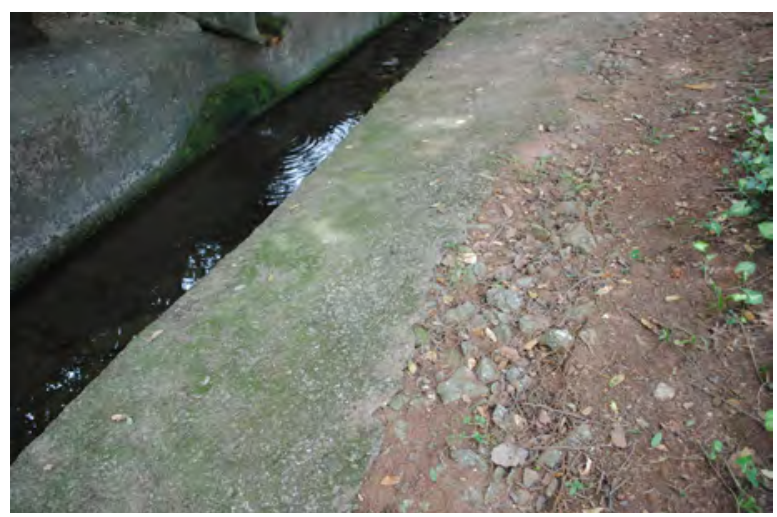

Figura 16: solapamento com exposição da armação.

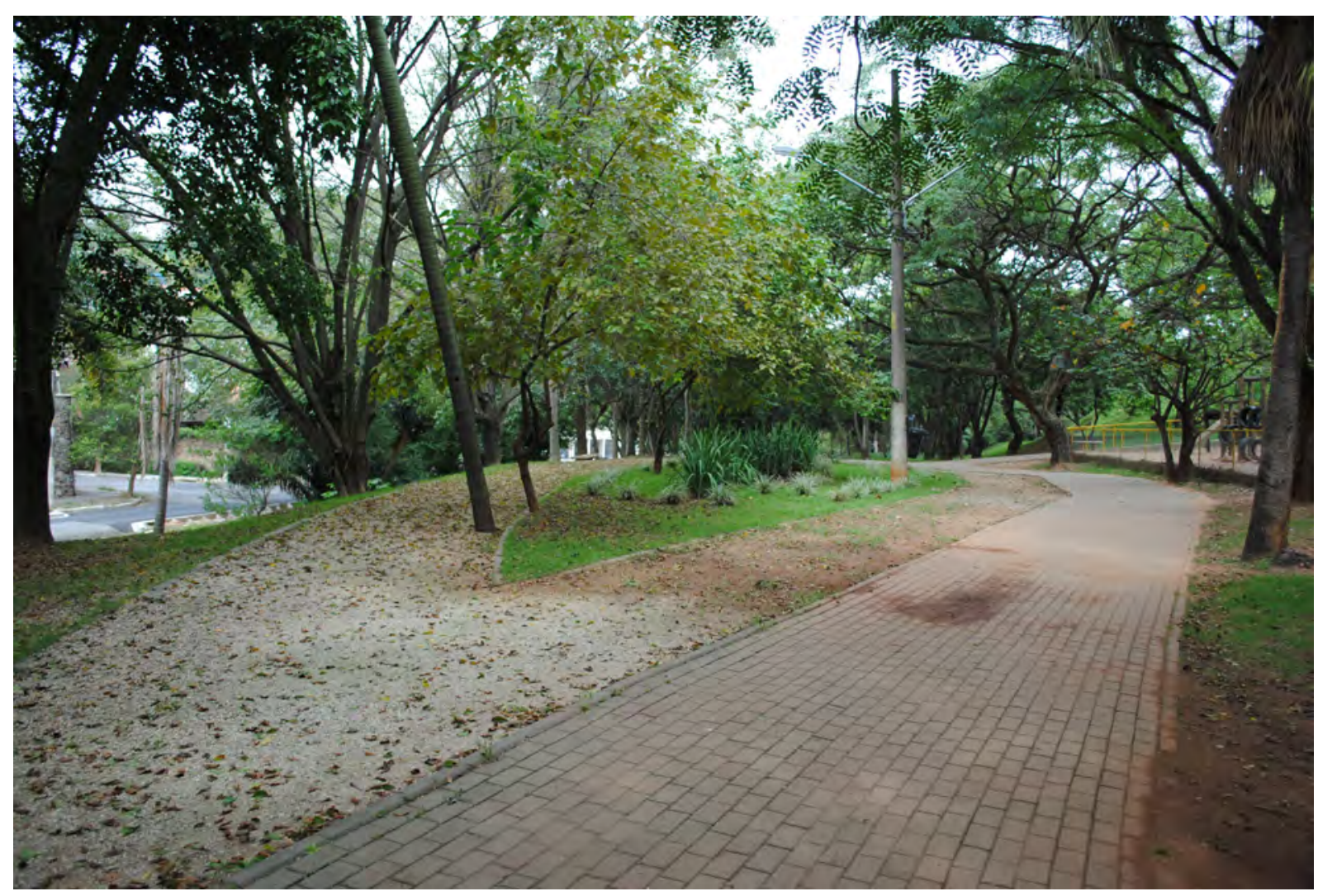

Figura 17: devido à falta de vegetação adequada, pisos estão frequentemente cheios de terra trazidos pelas águas das chuvas.

Especialmente reveladora foi uma visita a campo durante a forte chuva do dia 12 de abril de 2012, quando a estação pluviométrica junto à ponte da Cidade Universitária registrou a queda de $41,60 \mathrm{~mm}$ entre as $16 \mathrm{~h} 45$ e as $21 \mathrm{~h} 25$ (informações do SAISP Sistema de Alertas a Inundações de São Paulo). 
Foi possível entender com clareza o caminho das águas e identificar os impactos que a alteração imposta ao projeto original infligiu sobre a Praça Dolores Ibarruri.

Em um primeiro momento, saltou aos olhos a rapidez com que o nível do Córrego das Corujas subiu da sua habitual lâmina d'água que não ultrapassa os $20 \mathrm{~cm}$ para mais de 2 metros de altura. Em questão de 15 minutos, a água já extrapolava o canal, carregando vegetação, terra, sedimentos - e lixo - das margens.
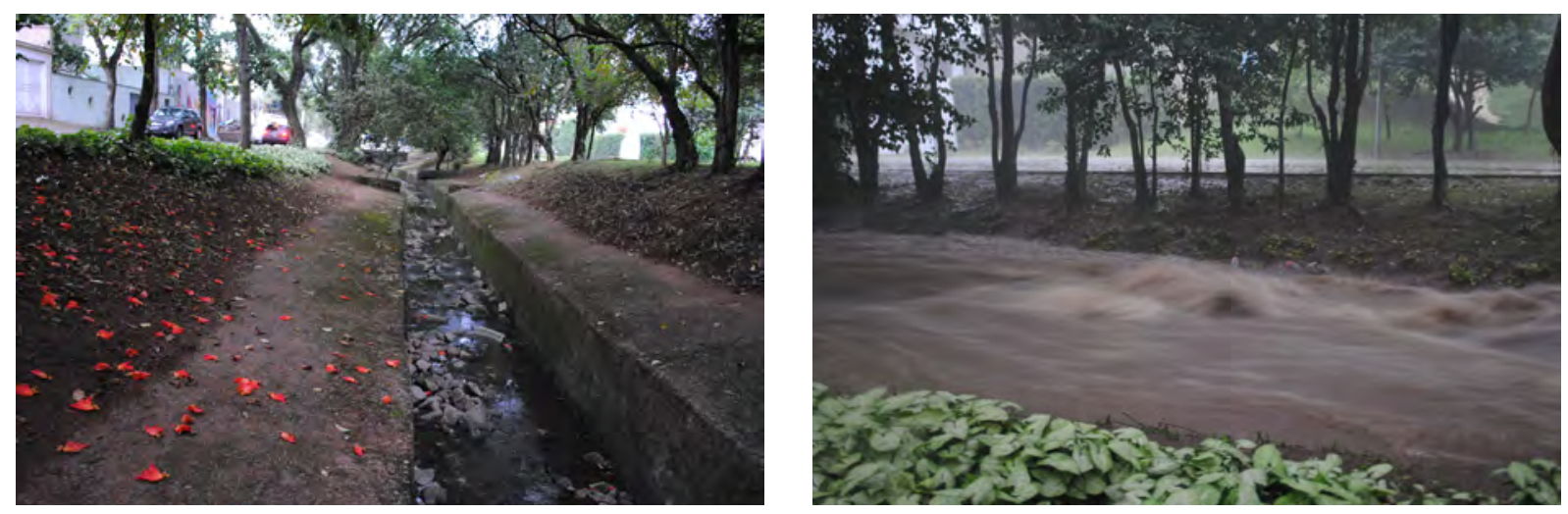

Figuras 18 e 19: lâmina d'água típica (foto de 03 de abril de 2012) e durante a chuva de 12 de abril de 2012.

A ausência das lagoas pluviais previstas em projeto aliada à concretagem de biovaletas aumentaram o escoamento superficial, acelerando-o até. $O$ resultado pode ser observado no claro processo de erosão nas margens do córrego. Esta evidencia ainda a importância do plantio de vegetação às margens. 

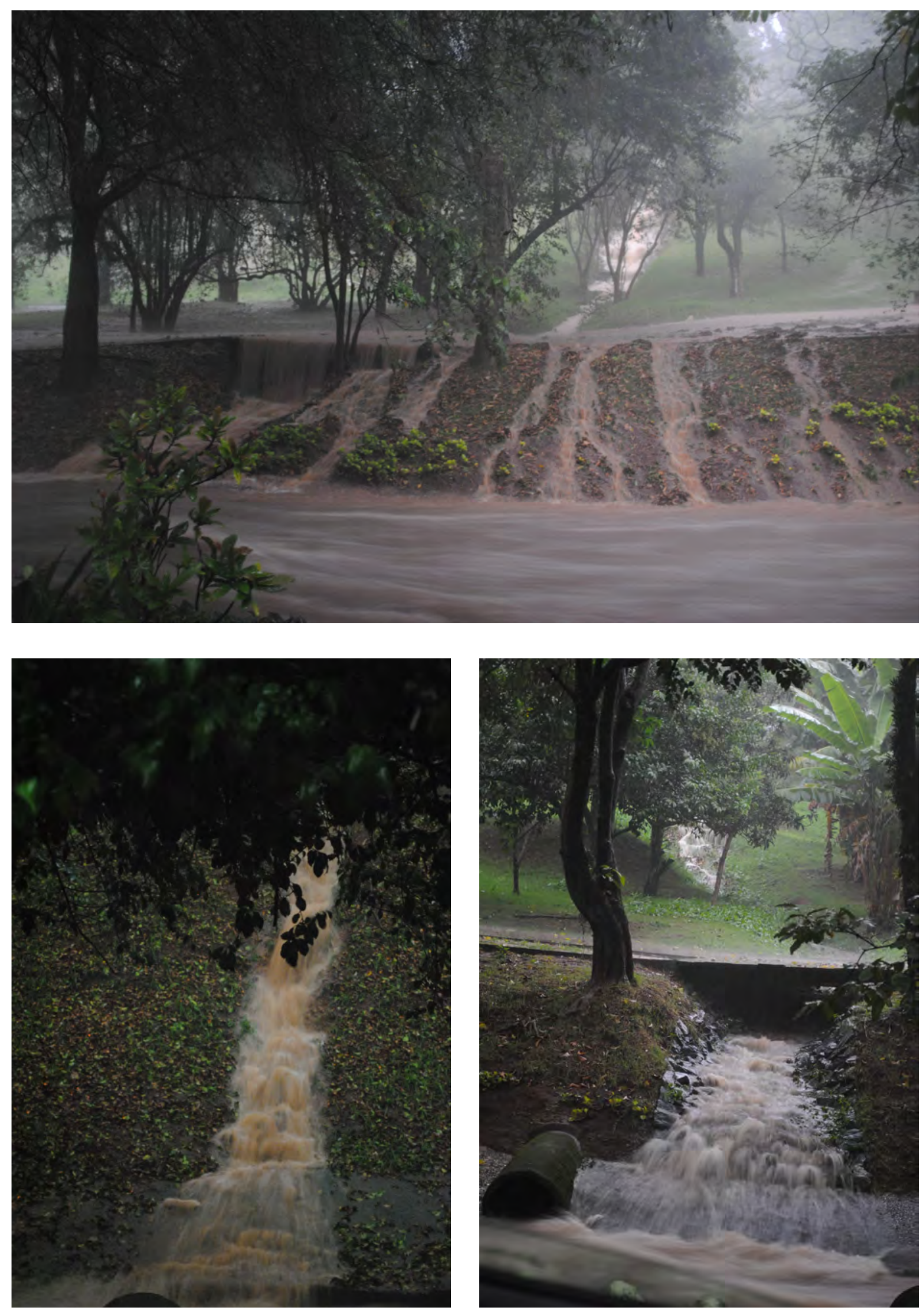

Figuras 20, 21 e 22: erosão de talude e velocidade da água nas 'biovaletas' concretadas. 
Constatou-se, ainda, que as galerias de águas pluviais estão sobrecarregadas, o que foi possível observar pelo refluxo dos bueiros. Em um deles a pressão da água foi tão forte que deslocou sua pesada tampa.
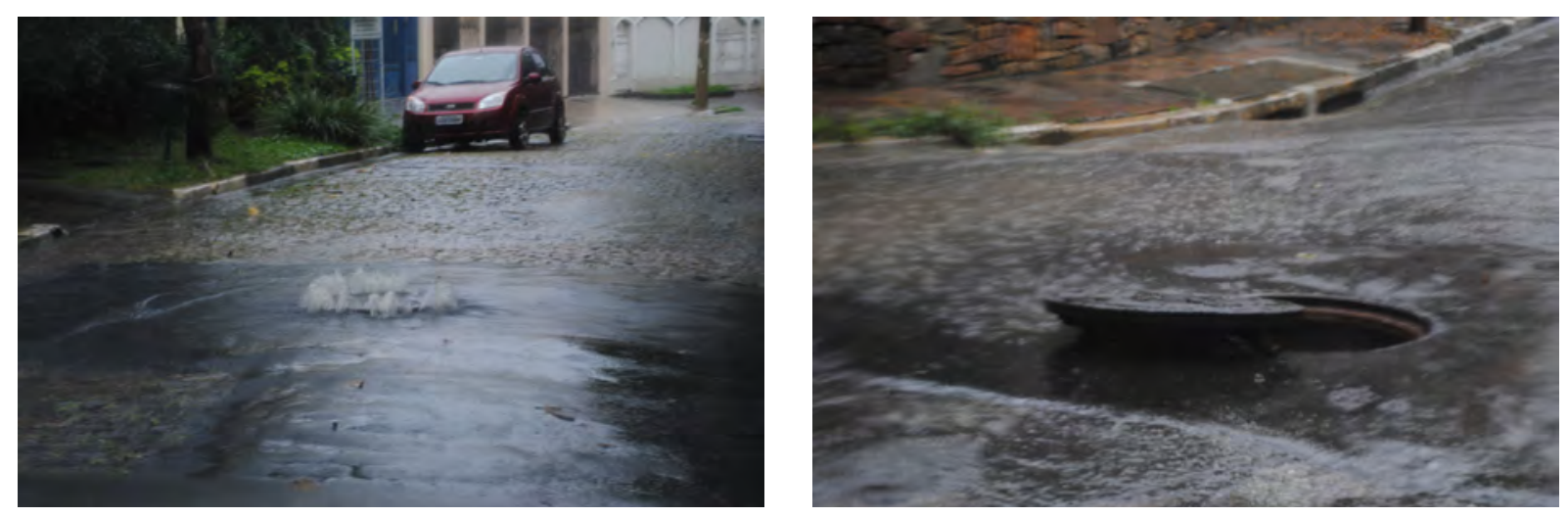

Figuras 23 e 24: sinais claros de que as galerias de águas pluviais estão sobrecarregadas.

Identificou-se também a necessidade de se repensar a calha do córrego. Além da já relatada altura que a água atingiu rapidamente, que por muito pouco não se sobrepôs à ponte da Rua Pascoal Vita, foi possível observar no começo da chuva que a velocidade do curso d'água no trecho em que o córrego recebeu muro de gabião é visivelmente menor do que no trecho em que o córrego foi concretado. Além da redução da velocidade, muros de gabião possuem a vantagem de aceitar vegetação, notadamente as que surgem espontaneamente, incrementando assim a capacidade de resiliência da praça.
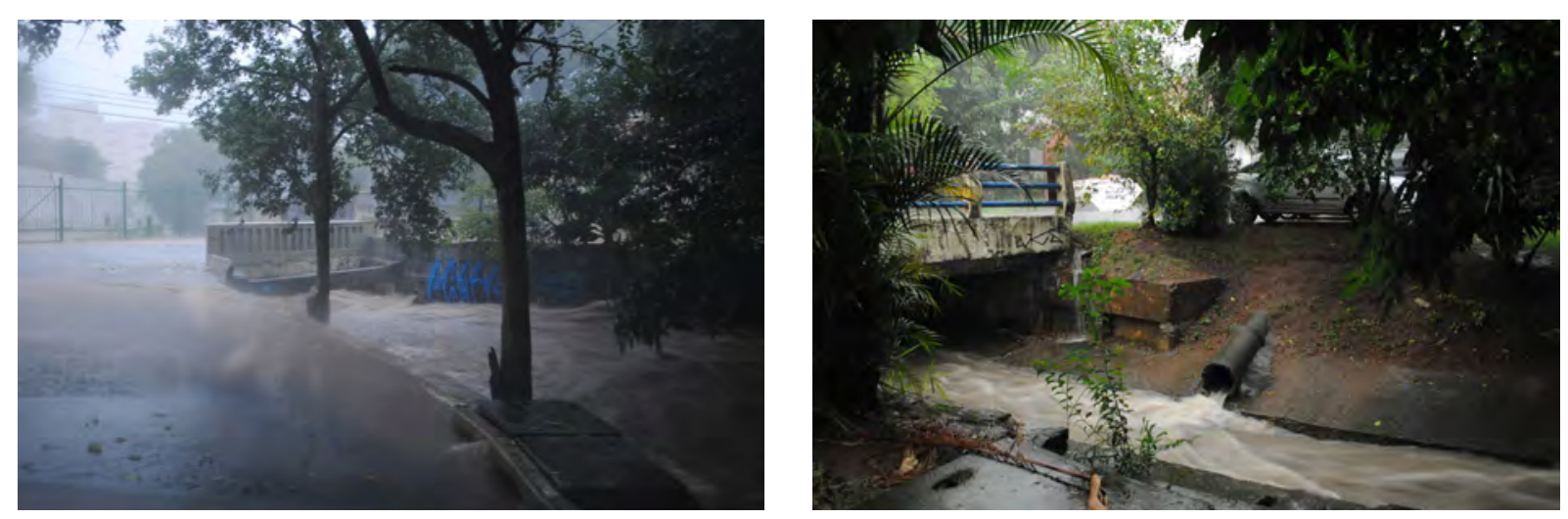

Figuras 25 e 26: nível máximo do rio durante a chuva e alguns minutos antes de seu pico. 


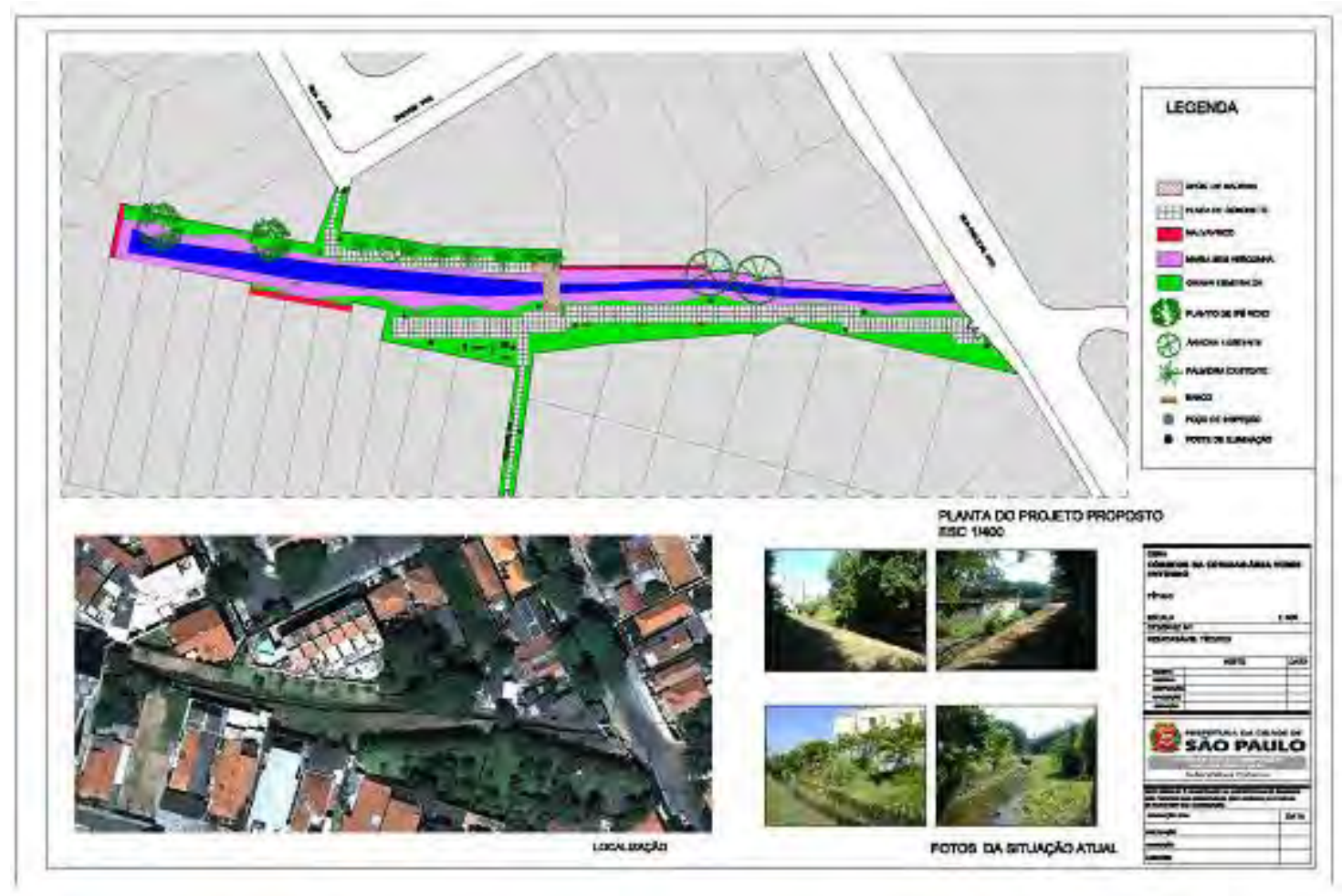

Figura 27: projeto apresentado pela subprefeitura de Pinheiros. Fonte: Associação Toca das Corujas Vila Beatriz. Disponível em < http://atcvb.blogspot.com.br/>. Acessado em 04/05/2012.

O Parque das Corujas, concluído em janeiro de 2012, foi concebido a partir da demanda de uma associação de moradores da Vila Beatriz ${ }^{11}$ e teve como objetivo o uso de uma gleba remanescente, na qual o córrego permanecia a céu aberto. Gleba esta que constituía uma das "sobras" de terrenos produzidas pela lógica da ocupação urbana que até então tinha os córregos como obstáculos ou incômodos à expansão urbana.

O projeto do parque contempla usos múltiplos em seus objetivos: a melhoria da drenagem, evitando que as casas do entorno sofressem com enchentes nas fortes chuvas e o uso para lazer e circulação não motorizada da gleba remanescente, até então degradada e com aspecto de abandono. Trata-se de uma gleba estreita e que se estende ao longo de cerca de 160m do curso d'água, a jusante da Praça Dolores Ibarruri. 
$\mathrm{Na}$ instalação do parque foi construído ao longo do córrego um caminho adequado às normas de acessibilidade universal e uma calha de gabião. Em visita à área durante $a$ forte chuva do dia 12 de abril de 2012 foi perceptível a redução da velocidade da enxurrada em função do gabião, se comparado ao trecho em que a calha é de concreto. Notou-se, ainda, um aparente melhor dimensionamento da calha do córrego que não extrapolou seus limites, diferente do que se observava no trecho do mesmo córrego na Praça Dolores Ibarruri, a montante do parque, onde a calha do córrego aparenta ser mais estreita. O parque contempla ainda alguns equipamentos de uma Academia da Terceira Idade - ATI e possui três acessos que levam a diferentes ruas do entorno.

Um item do parque que se destaca negativamente é a falta de arborização de modo a dar continuidade ao potencial corredor verde ao longo do curso d'água. Outro aspecto negativo do ponto de vista da drenagem urbana é que o caminho de pedestres foi construído com piso impermeável enquanto poderia garantir a percolação das chuvas. No gramado ao longo do caminho, até o presente momento, encontram-se apenas em um pequeno trecho palmáceas arbustivas e exóticas e uma mangueira, ambas previamente existentes no local.
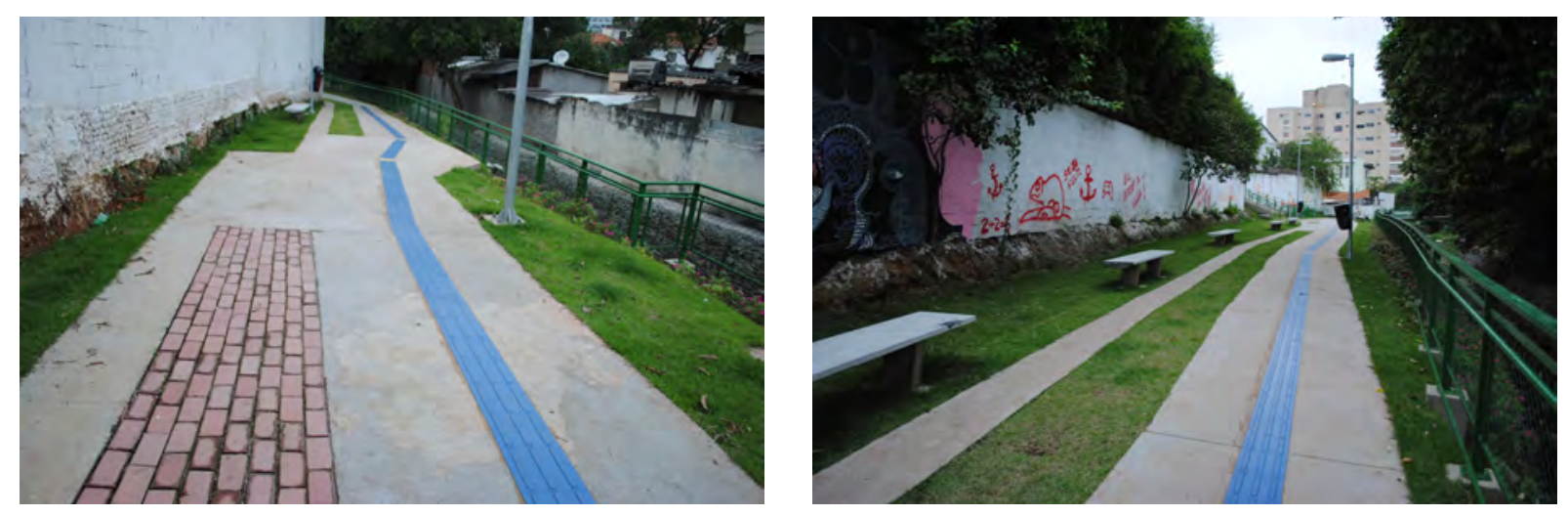

Figuras 28 e 29: o passeio de pedestres de piso impermeável e a falta de arborização do Parque das Corujas.

\section{CÓRREGO DAS CORUJAS: POTENCIALIDADES E LIMITAÇÕES}

A jusante do parque o córrego apresenta-se canalizado e tamponado em toda a sua extensão, até a chegada ao Rio Pinheiros. Na maior parte do seu curso, percorre galerias sob o sistema viário, mas em duas localidades específicas - no trecho subsequente ao parque, sob o restante da quadra, e após o sacolão da Rua Isabel de Castela - percorre galerias subterrâneas intraquadra. Neste último trecho, encontra-se sob o 
pátio de estacionamento descoberto de um conjunto de prédios. Vale destacar que o estacionamento é de piso impermeável e apresenta um canteiro central sobre um trecho parcial do córrego. Em levantamento cadastral dos terrenos realizado na presente pesquisa, constatou-se a propriedade privada dos lotes sob os quais o córrego foi canalizado nesses trechos.

A partir desse ponto, segue sob ruas até chegar na Rua Frederico Herman Junior, a qual percorre sob um canteiro central por toda a sua extensão - de aproximadamente $650 \mathrm{~m}$.

Os córregos tamponados são ocultados na já consolidada densa malha urbana da cidade. Da forma como discorre Bartalini (2011), eles tornam-se impedidos de se apresentar plenamente no mundo dos fenômenos visíveis e as marcas de sua presença tornam-se indiretas e muitas vezes imperceptíveis.

No Córrego das Corujas não é diferente. Assim, a reflexão que se propõe parte dos novos paradigmas do planejamento ambiental urbano, e indaga acerca de uma possível releitura do Córrego.

Não se propõe uma restauração ecológica propriamente dita, pois é notável que na densa malha urbana em que se encontra o córrego não haveria espaço nem condições para tamanha alteração em um meio com suas características naturais tão modificadas. Sabe-se, no entanto, que há outras formas de se resgatar a memória do córrego, mais adequadas à situação em que se encontra.

Travassos (2010) conceitua técnicas a cerca das quais se ancora a reflexão aqui intencionada ao citar uma prática que pode ser considerada de restauração e que tem ganhado adeptos ao redor do mundo, o "daylightining" (Pinkham, 2000; 2002) ou "trazer à luz". "As atividades relacionadas a essa prática abarcam desde tirar de galerias fechadas rios que estavam canalizados, recuperando-os em diversas gradações, até a simples indicação de que sob determinada rua passa um rio".

Esta última estratégia é explorada de maneira até mesmo poética por Bartalini em seu trabalho sobre os córregos ocultos, o qual inspira parte da reflexão aqui proposta.

A concepção deste trabalho teve início com visitas a campo nas quais o córrego em estudo foi percorrido em sua totalidade. Assim, foi identificada a área de suas nascen- 


\section{Revista LABVERDE}

tes e investigados seus vestígios até a chegada ao seu trecho a céu aberto. Foram observados e analisados os projetos já implantados nos trechos em que o córrego encontra-se aberto, ainda que canalizado e então, rastreando seus vestígios, foi localizado e às vezes deduzido o restante do seu percurso oculto.

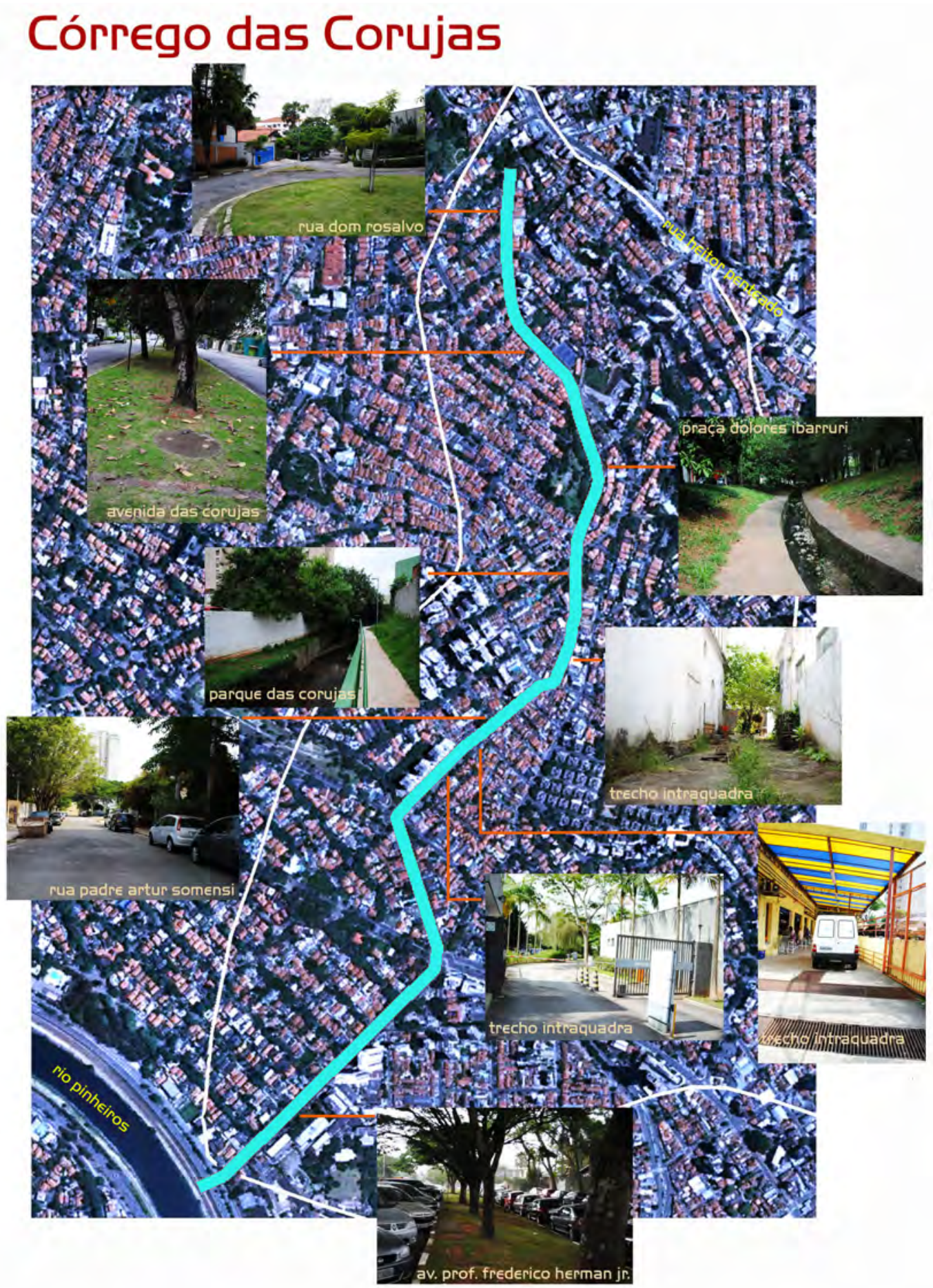

Figura 30: a bacia hidrográfica e o Córrego das Corujas com fotos ilustrando as diversas situações em que se encontra. 
A partir dessa investigação pretende-se propor uma reflexão a cerca da possibilidade de abrir o córrego nos trechos em que a operação se torna possível sem o prejuízo do entorno construído, ou mesmo do sistema viário já consolidado, e de revelar visualmente sua passagem nos trechos em que se mostre menos viável o destamponamento.

De acordo com Bartalini, "o córrego oculto, para comparecer na paisagem, não exigiria nem o literal vir à tona (...) na leitura dos seus vestígios / imagens. Já plenas de significados, essas imagens, ao integrarem as inúmeras paisagens possíveis, provocam a recorrência do córrego." (Bartalini, 2011, p.179)

Do ponto de vista biótico, indaga-se a cerca da possibilidade de se fazer um corredor verde ao longo de todo o curso d'água. Isso poderia se dar na forma de parques lineares nos trechos da Praça Dolores Ibarruri e do Parque das Corujas, na possível reabertura do córrego no canteiro central da Rua Frederico Herman Junior somado à uma arborização adequada de seu entorno direto neste trecho. No restante do seu percurso, através de uma intervenção capaz de revelar aos olhos a passagem do córrego, a arborização das calçadas e a constituição de um percurso adequado à circulação não motorizada.

Desta forma, o Córrego das Corujas seria inserido na rede de percursos e corredores verdes já contemplada no atual Plano Diretor Estratégico do Município de São Paulo, de acordo com a análise a seguir.

\section{IMPACTO AMBIENTAL}

Segundo Sánchez (2008), Impacto Ambiental é a diferença entre a provável situação futura de um indicador ambiental e sua situação presente, ou seja, a alteração de um determinado aspecto de qualidade ambiental através da implantação de um projeto.

A avaliação da qualidade ambiental parte sempre do Diagnóstico Ambiental que reúne indicadores do meio físico, do meio biótico e do meio sócio-econômico.

No âmbito de projetos que visem a recuperação ambiental da Bacia do Córrego da Corujas, pode-se tomar como referência três momentos distintos para se avaliar o impacto ambiental nos padrões de qualidade ambiental local. 
O primeiro momento diz respeito à situação anterior à implantação do Parque das Corujas e da reformulação da Praça Dolores Ibarruri. O segundo momento representa a situação atual. E o terceiro momento uma situação futura hipotética que contemple outras medidas de recuperação do córrego.

Antes da implantação do Parque das Corujas e da reformulação da Praça Dolores Ibarruri, a bacia do Córrego das Corujas apresentava uma situação muito semelhante à de diversos córregos da cidade de São Paulo localizados em meio à malha urbana consolidada, cuja função principal é de drenagem urbana e de recebimento de esgoto. As primeiras, e mais significativas, alterações em sua situação natural foram a retificação e canalização do córrego, que ocorreram a partir da década de 40 , e o recebimento de detritos e esgotos através do sistema de drenagem e de esgotos, que ocorreram gradativamente através da ocupação urbana.

Tais medidas levaram a impactos ambientais negativos significantes nos meios físico, biótico e sócio-econômico.

Em termos físicos, a retificação e a canalização do córrego acarretou em um desequilíbrio hidrológico na sub-bacia do Córrego das Corujas e tal impacto, associado a medidas semelhantes em outros córregos e rios da cidade, ocasionou uma alteração permanente de grande magnitude na Bacia do Rio Pinheiros. O resultado mais significativo desta ação é a ocorrência de alagamentos em diversos pontos. Já o lançamento de detritos, carreados pelo sistema de drenagem, e o lançamento de esgotos resultaram em açoreamento e perda da qualidade das águas.

Em se tratando do meio biótico, as medidas tomadas ao longo da segunda metade do séc. $\mathrm{XX}$, levaram à perda da vegetação ciliar do córrego e ao comprometimento da diversidade biológica associada não apenas às matas ciliares, mas também aos organismos presentes na águas antes próprias para o habitat de diversas espécies e agora comprometidas pelo lançamento de diversas substâncias poluentes.

Com relação à situação social e econômica da população do entorno, considera-se que em um primeiro momento, a retificação do córrego levou a uma valorização da região que permitiu o desenvolvimento de loteamentos que valorizaram economicamente a área através da possibilidade da ocupação de meandros, que antes não permitiam a ocupação devido à geometria do curso d'água e ao regime hidrológico. Entretanto, posteriormente, percebeu-se que a alteração passou a ocasionar alaga- 
mentos em diversos locais, fator que ocasiona desvalorização. Da mesma forma, o abandono de áreas verdes remanescentes, pela população e pelo poder público, levou ao aumento de ocorrências policiais na área, conforme relato de moradores. Associados, estes fatores tendem a ocasionar impacto negativo tanto em termos sociais como econômicos.

Num segundo momento, através da implantação do Parque das Corujas e da reformulação da Praça Dolores Ibarruri, houve uma melhora significativa em termos de qualidade ambiental já que a implantação dos dois projetos por pressão da sociedade civil local organizada levou não apenas à revitalização de áreas verdes abandonadas pelo poder público, mas também à inclusão de um trecho do córrego no programa Córrego Limpo, da Sabesp. A inclusão no programa da Sabesp buscou a melhoria da qualidade da água do curso d'água, através identificação e eliminação de pontos de lançamento de esgoto clandestino no sistema de drenagem que deságua no córrego. Hoje, apesar ainda a presença de lançamento de substâncias poluentes nas águas do Córrego das Corujas, é possível encontrar peixes de pequeno porte e outras espécies que retornaram ao curso d'água.

Da mesma forma, o projeto de revitalização da Praça Dolores Ibarruri, reivindicação de associações de moradores da região, teve por meta a recuperação da capacidade hidráulica do córrego, a adoção de medidas não convencionais de drenagem urbana e a implantação de caminhos e equipamentos para uso público. A implantação do projeto levou a melhorias no meio físico através da diminuição de enchentes, ao meio biótico através de um novo projeto paisagístico que se focou na utilização de espécies da flora nativa, e a melhorias sociais e econômicas decorrentes do aumento da segurança local ocasionado pela apropriação dos espaços livres pela população que os utiliza para lazer.

Em consequência da reformulação da Praça Dolores Ibarruri, a Subprefeitura de Pinheiros atendeu a solicitação das associações de bairro para a implantação do Parque das Corujas. Apesar de contar com dimensões bem mais modestas que a Praça Dolores Ibarruri, o projeto do parque buscou os mesmos resultados obtidos no outro projeto.

Em conjunto, a implantação do Programa do Córrego Limpo e a execução dos projetos do Parque das Corujas e da nova Praça Dolores Ibarruri resultaram em impacto ambiental positivo, com melhoria de diversos aspectos sócio-ambientais. Além disso, 
tais ganhos geraram repercussão na mídia, fato que auxiliou na conscientização da importância da valorização de fatores ambientais no desenvolvimento urbano e sua ligação com o aumento da qualidade de vida dos cidadãos.

\section{CONCLUSÃO}

A partir da análise dos projetos implantados na Praça Dolores Ibarruri e no Parque das Corujas foi possível concluir que o conceito de Desenho Ambiental pode ser aplicado com sucesso em áreas de ocupação urbana consolidada.

A possibilidade da propagação das medidas, amparadas nos novos paradigmas de Desenho e Planejamento Ambiental em outros trechos do córrego, leva a crer que haverá melhoria de qualidade ambiental significativa não apenas no entorno do Córrego das Corujas, mas em toda a sua microbacia e possivelmente nas microbacias vizinhas dos Córregos Verde e Belini. Com a implantação de uma ligação verde entre espaços verdes significativos haverá, por consequência, melhoria na Bacia do Rio Pinheiros. A possibilidade de ligar a cumeeira da bacia na Avenida Heitor Penteado com o corredor verde da Avenida Pedroso de Morais e, posteriormente, com as margens do Rio Pinheiros, interligando bacias vizinhas, representa um impacto de alto grau de importância para o Sistema de Áreas Verdes e para a Rede Hídrica Ambiental da cidade. Tal Sistema de Infraestrutura Verde harmoniza-se, portanto, com as propostas previstas no Plano Diretor Estratégico do Município.

Conclui-se que apesar das problemáticas citadas em torno da implantação dos projetos da Praça Dolores Ibarruri e do Parque das Corujas o impacto socioambiental das intervenções é claramente positivo e a adoção de novos paradigmas de desenho ambiental representa avanços rumo a um desenvolvimento urbano mais sustentável.

\section{REFERÊNCIAS BIBLIOGRÁFICAS}

BARTALINI, Vladimir. A trama capilar das águas na visão cotidiana da paisagem. São Paulo: Revista USP, 2006.

Os córregos ocultos e a rede de espaços públicos urba-

nos. São Paulo: Arquitextos, 2009. 
Córregos ocultos em São Paulo. In: Reis, Almir Francisco. (Coord.) Arquitetura,Urbanidade e Meio Ambiente. Florianópolis: Ed. Da UFSC, 2011. BENEDICT, Mark A., e MCMAHON, Edward T. Green Infrastructure: linking landscapes and communities. Washington: Island Press, 2006.

BONILHA, Iraúna. A água e os rios na cidade: Elementos para o projeto ecológico da paisagem. Paisagem e Ambiente - Ensaios. São Paulo: FAUUSP, n.22, p. 172-179, 2006.

CORMIER, N; PELLEGRINO, P. Infra-Estrutura Verde: uma estratégia paisagística para a água urbana. In: Paisagem e Ambiente n. 25. São Paulo: FAU-USP, 2008.

FERREIRA, José Carlos; MACHADO, João Reis. Infra-estruturas verdes para um futuro urbano sustentável. o contributo da estrutura ecológica e dos corredores verdes. Revista LABVERDE. n. 1, out. 2010, 68-90 p.

FIREHOCK, Karen. Short history of the term Green Infrastructure and selected literature. Disponível em: <http://www.gicinc.org/PDFs/GI\%20History.pdf>. Acesso em: $11 / 08 / 2011$.

FRANCO, Maria de Assunção Ribeiro. Desenho Ambiental - uma introdução à Arquitetura da paisagem com o paradigma ecológico. São Paulo: Annablume: FAPESP, 1997.

Planejamento Ambiental para a Cidade

Sustentável. São Paulo: Annablume: FAPESP, 2001.

Infraestrutura Verde em São Paulo: o caso do Corredor Verde Ibirapuera-Villa Lobos. Revista LABVERDE.n.1,out. 2010, 134-154p.

FRIEDRICH, Daniela. A visão ambientalno planejamento e gestão de parques lineares em áreas de fundo de vale urbana. In: O parque linear como instrumento de planejamento e gestão das áreas de fundo de vale urbanas. Porto Alegre,2007. Dissertação (Mestre em Planejamento Urbano e Regional) -Faculdade de Arquitetura, Universidade Federal do Rio Grande do Sul. 
HOUGH, Michael. Naturaleza y ciudad: Planificación Urbana y Processos Ecológicos. Barcelona: Gustavo Gili, 1998.

MAGALHÃES, Manuela Raposo. AArquitectura Paisagista - Morfologia e complexidade. Lisboa: Editorial Estampa, 2001.

MARTINS, Larissa Arakawa. Avaliação do desempenho das tipologias paisagísticas de drenagem natural da Praça Dolores Ibarruri em São Paulo - SP. Relatório Parcial. FAUUSP. 2012.

MC'HARG, lan L. Proyectar con la naturaleza. Barcelona: Gustavo Gili, 2000.

SANCHÉZ, Luis Enrique. Avaliação de Impacto Ambiental : conceitos e métodos. São Paulo, Oficina de Textos, 2008.

SANTOS, Milton. Técnica, espaço, tempo: globalização e meio técnico-científico informacional. São Paulo: Hucitec, 1994.

SÃO PAULO (Município). Plano Diretor Estratégico do município de São Paulo - Lei n. 13.430, de 13 de setembro de 2002. São Paulo, 2002a.

. Secretaria Municipal do Verde e do Meio Ambiente - SVMA; Secretaria Municipal de Planejamento Urbano - Sempla. Atlas Ambiental do município de São Paulo. São Paulo: 2002b.

SPIRN, Anne W. O Jardim de granito. São Paulo: Edusp, 1995.

TRAVASSOS, Luciana Rodrigues Fagnoni Costa. Revelando os rios: Novos paradigmas para a Intervenção em Fundos de Vale Urbanos na Cidade de São Paulo. 2010. Tese (Doutorado em Ciência Ambiental) - Universidade de São Paulo.

VEIGA, José Eli da. A emergência socioambiental. São Paulo: Editora Senac, 2007. 